\title{
DATA ACQUISITION FOR THE CREATION OF THE PREDICTION MODEL
}

\author{
Monika Šimánková
}

Klíčová slova:

Odměňování zaměstnanců, predikční model, odměňovací systémy

\section{Key words:}

The managemet of rewards, the prediction model, the payment system

\begin{abstract}
Abstrakt
Článek se zabývá teoretickými i practickými východisky pro tvorbu predikčního modelu tzn. shrnutím teoretických poznatků z hlediska odměňování zaměstnanců dělnických profesí dle výkonu. Dále pak popisem př́kladů tohoto odměňování získaného z výzkumu zakázkových strojírenských společností. Na základě těchto informací pak tvorbou predikčního modelu zaměřeného na výběr správného typu odměňování a zobrazení výsledků použití tohoto modelu ve finančních datech společnosti.
\end{abstract}

\begin{abstract}
This article focuses on theoretical and practical information, which is necessary for the creation of the prediction model; that means collecting theoretical information from the point of view of rewarding manual workers according to their performance. It also describes examples using this kind of rewarding, gained from research of custom machinery companies. The prediction model was created on the basis of this information, concentrating on the choice of right rewarding payment system and the display of results of the using the selected model on the company's financial data.
\end{abstract}

\section{Introduction}

The rewarding systems have a direct influence on the running and efficiency of a company. With the right selection of the rewarding system, and its correct setting, we would be able to significantly influence revenues and costs of a company. The aims of this article are to acknowledge the main features of the rewarding of manual workers, to describe the individual models of rewarding and to summarize their pros and cons. The prediction model was created on the basis of the knowledge and the database of the most frequently used models by custom engineering companies, obtained during the research of custom engineering companies which took place in 2009 and $2010^{1}$. The prediction model will select a suitable rewarding system on the basis of process of selection. The next step is the setting of the curve of rewarding. The initial point for the setting of the curve of rewarding is the analysis of the transition point of a concrete company. The rewards are assigned pursuant to the curve with the connection to the enhanced performance. The enhanced performance and increased price of the paid rewards, such as salaries, can be seen along with other changes, in the return of profits and losses, which is used when displaying the effectivness of the rewarding system on an examined company. Even where there are two basic rewarding principles used in the model, their outputs are showed similarly (picture 1) for better orientation for a user.

\footnotetext{
${ }^{1}$ Simankova M: Stimulační systémy zakázkových strojírenských společností (výsledky průzkumu), 2011. Dostupné online na http://stimulacni-systemy-zakazkovy.vyplnto.cz.
} 


\section{Rewarding Systems According to the Results for Manual Workers}

Rewarding systems according to the results, stimulate workers by assigning their salary, or part of it, to their working performance (the number of items they produce etc.). The main types of rewarding systems according to the quality of work of an individual can be summarized as follows:

1. task salary

2. the norming system of work

3. salary with a gauged daily performance

4. rewarding according to the results

5. group or team rewards

Group or team rewards are usually used by companies which have a problem with acknowledging the individual performance of an employee, e.g. custom manufacturing companies.

The following chapters are focused on comparing of rewarding systems according to the results for manual workers.

\subsection{Task Salary}

The reward depends on the output. It has significantly restricted usage in the fields in which the employee's output is dependant on the amount of produced items, e.g. agriculture, fashion industry, processing industry.

\begin{tabular}{|l|l|l|}
\hline \multicolumn{2}{|c|}{ Pros } & Cons \\
\hline Enqloyer & $\begin{array}{l}\text {-direct motivating } \\
\text {-simple make }\end{array}$ & $\begin{array}{l}\text {-losses of the control of the output } \\
\text {-problem with guility }\end{array}$ \\
\hline Erqloyee & $\begin{array}{l}\text {-possibility of short-term } \\
\text { foressing of earnings } \\
\text {-independent regulation of work rate }\end{array}$ & $\begin{array}{l}\text {-earnings can be hardiy foreseen } \\
\text { in the long term perspective } \\
\text {-work can be stressful } \\
\text {-repeating of a work routine } \\
\text { can case illness }\end{array}$ \\
\hline
\end{tabular}

Figure 1: Comparing Pros and Cons of using task salary

Source: adapted according to Armstrong 2007

\subsection{The Systems of a Regulation of Work}

The regulation of work is used for determining standardized levels of outputs during a certain period, or norms of the consumption of time for work or task. The bonus depends on comparing norms of per formance with the real performance or the saving of time. 


\begin{tabular}{|c|c|c|}
\hline & Pros & Cos \\
\hline Employer & $\begin{array}{l}\text { - it seems like a scientific method connecting of } \\
\text { the rewards with the performance and can lead } \\
\text { to significant growth of producitivity at least } \\
\text { short-termed }\end{array}$ & $\begin{array}{l}\text { - can be hardly implement } \\
\text { - can degenerate and cause disproportionated growth of } \\
\text { salaries when the norms are wrong } \\
\text { - system are expensive and time consuming }\end{array}$ \\
\hline Employee & $\begin{array}{l}\text { - the method of a connection of the salary } \\
\text { with performance } \\
\text {-employees can be included in the process } \\
\text { of a norm-making }\end{array}$ & $\begin{array}{l}\text { - making the norms can be subjective } \\
\text {-earnings can be changing according to request on work }\end{array}$ \\
\hline
\end{tabular}

Figure 2: Comparing Pros and Cons of regulation of work

Source: adapted according to Armstrong 2007

For work which repeats itself in short periods of time and where the changes in the structure of work or form of work are rare, postures are restricted and managers or masters are able to sustain it and manage it.

\subsection{Salary with a Gauged Daily Performance}

The reward defined by the highest rate on the basis of keeping the high level of performance, is measured by certain standards. Everyone has to be completely devoted to accomplishing their work.

\begin{tabular}{|l|l|l|}
\hline \multicolumn{2}{|l|}{ Pros } & Cons \\
\hline Enployer & $\begin{array}{l}\text {-employees are obliged to achieve } \\
\text { the concrete level of performance }\end{array}$ & $\begin{array}{l}\text {-goals of performance can became easily achieved } \\
\text {-can be hard change the goals of performance }\end{array}$ \\
\hline Enployee & -offers highly predictable earnings & $\begin{array}{l}\text {-employees do not have opportuninty to be rewarded } \\
\text { according to their performance }\end{array}$ \\
\hline
\end{tabular}

Figure 3: Comparing Pros and Cons of using salary with a gauged daily performance

Source: according to Armstrong 2007

Having high standards for the measurement of the work is important. Good systems of control and recognition of defects need to developed during an accomplishment of tasks.

\subsection{Rewarding According to the Results}

Reward for the basic rates referring to the evaluation of the individual performance.

\begin{tabular}{|l|l|l|}
\hline \multicolumn{2}{|l|}{ Pres } \\
\hline Enployer & $\begin{array}{l}\text {-rewarding individual contributin without } \\
\text { neccessity of measuring or tegulate } \\
\text { the work } \\
\text {-suitable for manufacturing branch } \\
\text { with high technology }\end{array}$ & $\begin{array}{l}\text {-theasuring or judging of performance can be hard } \\
\text {-does not bring no direct invitation }\end{array}$ \\
\hline Enployee & $\begin{array}{l}\text {-opportunity to be rewarded } \\
\text { for performance }\end{array}$ & $\begin{array}{l}\text {-judging working performance can be defected } \\
\text { and inconsistent }\end{array}$ \\
\hline
\end{tabular}

Figure 4: Comparing Pros and Cons of usisng rewarding according to the results 
As a part of the program of harmonized rewarding (manual and other workers). Also, as an alternative of the systems of regulation of work or improvement of the systems of daily rates.

\subsection{Group or Team Rewards}

For groups or teams the rewards (and bonuses) are paid on the basis of their performance in how they accomplished the norms or achieved the goals.

\begin{tabular}{|l|l|l|}
\hline \multicolumn{2}{|c|}{ Pros } & \multicolumn{2}{|c|}{ Cons } \\
\hline Enployer & $\begin{array}{l}\text {-encouraged team work } \\
\text {-are not individualized }\end{array}$ & -direct necouraging effect can be restricted \\
\hline Enployee & $\begin{array}{l}\text {-rewards clearly depends on common } \\
\text { performance of group } \\
\text {-minimalizing swaying of earnings }\end{array}$ & $\begin{array}{l}\text {-does not respect individual performance and } \\
\text { contribution }\end{array}$ \\
\hline
\end{tabular}

Figure 5: Comparing Pros and Cons of using group or team rewards

These rewards are suitable when team work is important; therefore, the effort of the team can be measured and judged as an alternative to an individual measuring, according to the results in cases where the latter is ineffective.

\section{Components of the Controlled Rewarding}

\subsection{Basic Financial Reward}

Basic financial reward (basic salary) is a firm salary which is made from a rate of a specific work or work space. For manual workers, usually a wage is used which coincides with the profession of the employee (called the rate) he or she has in a company. Usually, there is an added incentive payment to the wage. It is an appreciation of experiences, knowledge and skills of the employees, which is expressed by adding a sum (e.g. 1-20 CZK) to the wage. These two basic components form the part of the salary, which an employee earns in connection to the number of worked hours, regardless of any other factors on his performance. The advantage of these systems is that it gives the employer the option to set the table of the incentive payment, according to skills preferred by him etc. It also gives the opportunity to financially evaluate the employees who are better contributers to a company. The disadvantage is that, if this system is used as the only rewarding system without any other motivation or rewards, it can lead to the employee consuming the biggest amount of worked hours. If the amount of worked hours is not measurable or comparable to normed hours assigned to a task, it can lead to higher expenses.

Basic financial reward can be the base for determining additional rewards depending on performance. Levels of financial rewards are managed by the fluctuation of the rates on the market, according to the development of inflation or the influence of collective agreement etc. Basic salary can be expressed yearly, monthly, weekly or hourly (time rate).

\subsection{Additional Financial Rewards}

Apart from the basic financial rewards that the employees are paid, the so called additional financial rewards, can be divided as follows: 
- Individual performance rewards, where the reward depends on the quality of the performance

- Extra rewards - rewards for successful performance which are paid as a firm sum, depending on the results

- Bonuses - rewards depending on the achievement of the goals set in advance

- Commission - special form of incentive, where the salesmen's rewards are formed on the base of percentage from the value of sales

- Reward depending on the length of employment - reward which is enhanced by the firm value on the scale depending on the length of employment.

- Reward according to the skills - reward which is distinguished according to the level of achieved skills of an individual.

- Reward according to the ability - reward which is distinguished according to the achieved level of abilities.

- Supplementary charge - parts of the rewards, which are provided as divided financial sums for overtime, work in shifts, working emergency, living in a capital city etc.

- Reward according to the contribution - reward relating to the contribution of work or the skills of an individual.

The total amount of an employee's earning consists of the basic financial reward along with all the additional financial reward. The structure of a salary and the way of calculating its individual parts, have to be transparent and readable for all employees to whom it applies, in order for it to be successful.

In the following chapters we are going to deal with the first mentioned type of rewards, which is individual reward according to performance.

\section{The Prediction Model}

The prediction model has been developed on the basis of the experience with the creation of rewarding systems for a machinery company. During the development of this model, several problematic areas and a number of questions have arisen. I tried to clarify and solve the problems by developing this model.

There are several goals in the process of rewarding employees. An increase of their productivity or effectiveness of their work is one of them. The next one is fair rewarding and contentment of the employees. During a development of a company's rewarding system, the management has several question which require an answer, such as, „How much will it cost? Which benefits do I get? How big of a share of the profit do emoployees get? What is the optimum rate between revenues and costs?". But at the beginning of the development of a rewarding system, the questions are much simpler.

As a manager of such a company, I decided to establish a rewarding system. What are my options? Which of the already existing rewarding systems are useful for the rewarding of the efficiency of employees? What are the conditions that have to be fulfilled so that a particular model can be established. I have chosen to answer these questions by creating a prediction model.

\subsection{The Process of Making a Decision}

The process of making a decision begins with the prediction model. The manager answers some questions to find out which model is best suited for his company. The process of 
making a decision will show him this model. Of course, it is possible to choose a different model than had been recommended, but then it is neccessary to turn to a page, where individual models and the conditions for their application have been already described, including the necessary HW and SW.

\subsection{The Database of Models}

The database of individual models has been created with a connection to the research of engineering companies and the rewarding systems they are using, which took place in the years of $2009-2010^{2}$. After processing the results of this research, I was very surprised to find out that each of the researched companies are using the three basic types of rewarding employees, in manual professions.

Minor companies are still using rewarding of employees according to the decision of a foreman. The sum for a cost center is most frequently assigned according to the management's decision, the fulfillment of a plan, or the results of managing in a previous month, quarter etc. without further inquiry into the performance of an individual. This model of rewards was not included in the database of models of the prediction model, because there are no relations to the performance of the individual or a group.

The next model is the model of productivity. It's the type of a rewarding that is assigned to a group, a team or a cost center (Chapter 1.5). Productivity is counted for a marked period, according to a performance and worked hours or according to a performance and a paid sum of salaries. More detailed appearance of a numerator of the productivity is different from case to case, starting with a gross productivity and ending with a subtraction of various accounts, according to a management's decision.

Productivity of work can be generally defined as an input or output of, for example, work. The number of workers or the amount of their worked hours are usually used as an indicator of productivity. Added value is also an indicator of productivity. The added value is a value of production and subconsuption. The value of production are revenues for a production (or a revenue) and subconsuption are expenses for material, crude and services for a company. ${ }^{3}$

As an illustration of measuring according to a productivity of work, I am going to describe a model used by one of the researched companies. Productivity of work is the system of measuring the performance, established on the basis of a mutual division of assets (performance, added value, receipts etc.) and the number of consumed items used for its achievement. In this case, the following calculation is selected:

a) Receipts (minus cooperative work)

b) The number of re-counted worked hours

Formula 1: Calculation of productivity of labour

The main reason for selecting simplified items in a numerator and a denominator is the easy and quick accessibility of data. It will determine the gross productivity of the work of an employee, per hour.

\footnotetext{
${ }^{2}$ Simankova M: Stimulační systémy zakázkových strojírenských společností (výsledky průzkumu), 2011. Dostupné online na http://stimulacni-systemy-zakazkovy.vyplnto.cz.

${ }^{3}$ Synek M. a kol.: Manažerská ekonomika. Praha 2006, Grada publishing. s.268. ISBN 80-247-0515-X.
} 
The item of a denominator, "the number of re-counted worked hours", is calculated from the number of hours, completed by employees of an observed group for a set period of time. The completed worked hours are divided as normal working hours and hours worked in overtime. Overtime hours are calculated by a coefficient of bonus (e.g. $25 \%=1,25)$. The reason for this was an effort to reduce the overtime work. Similarly to other companies, this company as well, enountered a problem with shifting the work to better paid hours (overtime, Saturdays, Sundays), although it was not neccessary. By "handling" the rewards on this parameter we can conclude that the employees get their bonus for working in normal hours and do not have to "push" the work to the overtime.

The item of a numerator is probably the biggest weakness of the whole operation. It is obvious that receipts contain a certain margin or a percentage of the profit which is set differently for every customer. The composition of commissions can influence the efficiency of a group without its contribution. After a revision, it has been discovered that the composition of individual monthly commissions (with small exceptions), the group works every month on the more profitable and less on the least profitable. With a mutual summation in a month, the differences in the metamonthly achieved earnings are inexpressive. Subtracting the price for cooperative work, ensures that the sum of the receipts will be reduced by a cooperant's work, with no connection to the observed group.

The indisputable advantage of this calculation, (except the already mentioned accessibility of data), is the fact that enhanced productivity is directly connected to enhanced capacity of receipts or reducing working hours, which has a substantial effect on achieved profit. An employee's bonus can be, without any doubt, paid from the obtained profit. Theoretically, a situation should not arise (with only an exception) when there would not be enough money for calculated rewards. It could only happen if the employees were achieving high productivity, but the group was in loss.

This situation could only happen if the capacity of receipts (and worked hours) were under the transition point. It can happen when a company's turnover is under the break even point. We have to include this parameter, which happens every year, during a determination of the limit of productivity and reward for its achieving or crossing.

Determination of the limit of rewarding is connected to the strategy of the company and the goal of the additional reward. In our case, the goal was to find the rewarding system, depending on group rewarding. This means to find out the system of rewards which would, depending on performance, determine the sum of the reward and ensure the achievement of economical goals of the company, above all the profit before taxing. The next aim was easy deductibility and a possibility of a weekly evaluation so the group could, in a short period, react to performance failure etc.

The first step is determination of the average sum of the parametre. The sums of the parametres (receipts-cooperations) needed to be calculated, in a particular time in the past, and the number of recounted worked hours, in individual months. The selected period is connected to the history and the development of a company. If the company has every year, a similar capacity and structure of profits, we can use the similar capacity of employees from the previous year. But if the numbers of these parametres change, we have two options. Firstly, we can choose a shorter initial period or a plan of the company. The plan of the company can be only used in a certain case when the company has established capacity planning. Secondly, on a basis of obtained data, we can determine an average productivity of 
a company. This sum can also be the initial limit for measuring, or it could be even a higher sum connected to the enhancement of a performance.

If we have determined the average sum, the next step would be to numericaly express what the enhancement of the parameter means. We have to consider this, if we want to influence the achievement of the average sum of productivity with an initial sum. If the average sum matches the sums defined in the plan of the company, the achievement of the average sum could mean initial reward.

The third used model is the rewarding according to the fulfillment of norms (the model of norm). It is one of the variety of the systems of a norm work (chapter 1.2) where the sum of a reward is meant for a group or an individual, according to the rate of a normed and a worked time or a normed time and actual finished pieces.

The biggest advantage of this reward is considered to be the calculation of the reward for the last employee. There is no problem with dividing the sum to the groups of workers and its subsequent re-dividing to the leaders of the groups and their subordinates, which is usually influenced by subjective feelings towards the employee. The whole system is tightly connected to the system of norms. Therefore, it is very important that a company that decided to establish this system, could rely on the stystem of establishing norms and the norms themselves. It is unacceptable for norms to be weaker and stricter for various professions. We can hardly think that all the norms will be the same, but it is important that the certain inaccurateness (if any) was equally placed on all professions and workplaces. It is also neccessary not to let the system of norms halt on one point, and to run controlled updates. Why controlled? Manipulating with the norms can influence the sum of a reward. This means that technologists (or any other employee taking care of the system of norms) have to be objective towards the employees for whom they count the norms. Their objectivity and efficiency during the calculation of the norms can be corrected by their own system of rewards.

Once again for an illustration I am going to describe a model used by one of the researched companies. We used the following formula:

\section{a) Sum of standadized time per an unit $=\%$ fulfilment of the standards \\ b) Sum of time usage per an unit}

Formula 2: The calculation of the performance of employee

The calculation of the performance of employee looks as follows: With every beginning of an operation it signifies the start of work. With the usage of a barcode it marks the products it started the work on and the operation it works on. ${ }^{4}$ When it finishes the work, it uses the barcode on the technological procedure to mark the ending of the work and the number of finished products. After finishing the operation and announcing the number of finished products, the system performs tasks of assigning the norm and worked time. The assigning of the norm looks as follows: norm per operation multiplied by the number of finished products.

\footnotetext{
${ }^{4}$ Every product is provided with its own technological procedure which arises from the graphical documentation. Technological procedure includes several operations, one after another. Each operation has its own barcode, which includes an identification of the product, producing command and operation.
} 
At the end of an observed period (week, month etc.) there will be a summation of all normed and actual worked hours per employee, and the performance of the worker will be calculated. Individual workers are assigned to groups, according to the group's connection to profession or cost center of the products. It matters what groups we want to evaluate. We will count the number of normed and actual working hours per group and evaluate its performance.

Another advantage of this system is the possibility of observing the performance of individual workers, groups, cost center during any period, and comparing the performance to individual ones. With this system, it can be found out what influences the performance of the workers, such as product composition of the commissions, various months in a year, seasonality etc. With this data there is no problem to prepare any graphic display of the results of individual or group for the decision of the management.

\subsection{The Calculation of the Reward for Performance}

Now that we know how to determine the efficiency of individual employees and groups of employees, the question is who is to be rewarded. However, the question of who will reward the employees for their performance remains. This system of rewarding works with a presumption that higher fulfillment of norms, will mean more finished commissions in the same time, resulting in an increase of profits. Employees get some share from newly added profit to the company.

During the determination of the limit for a reward, it is very important to carefully consider the veracity and credibility of the amount of the norms. All of the companies I researched so far, were able to shorten the norms of time for an operation (if we consider manufacturing, not machinery) by $30 \%$ in a few phases, using this performance reward or a very similar rewarding system. Estimating the objectivity of norms and possibilities of their fulfillment by employees is the initial point for determining the limit for the reward. If I can estimate that employees, according to my professional skills are able to enhance their performance by $20 \%$, then it would be effective to increase the pace of additions by $20 \%$.

The calculation of the reward itself comes from an hourly rate of an employee. In this point there can be a certain variance. The public is divided into two main groups. The first one agrees that the hourly rate for an employee designates his importance for an employer, because the rate increases when there is better performance etc. Therefore, his reward should reflect the employee's skills. The second group states that for the same enhancement of performance the reward should be the same, so we should use the average hourly rate. The decision is once again left up to the employer. The calculation of the reward from this point on is easy. The hourly rate is multiplied by the number of worked hours, further multiplied by the increase of the reward.

\subsection{The Displaying of the Model}

Two basic types of rewarding are put into the prediction model, according to the achieved productivity (the model of productivity) and fulfillment of norms (the model of norm). Both models are displayed similarly for an easier orientation.

The picture of the model, indicated below, contains a shortened income statement displaying the influence of expenses and yields of the management of a company. The model has been created on the basis of a case study from a selected company. Used data is factual and the correct function of the system has been verified by the management of the company. 
For the purpose of displaying the influence on the income statement of the model, it has been divided into two accounts; variable and fixed. Sales were assigned to variable accounts. Expenses relating to rewarding were assigned to a table of the rewards of a particular model. The income statement is used for better understanding of its development during individual performances of a company, which is displayed in five back-to-back months. There is a possibility to choose any performance, fulfilling the norms or productivity, and related assignment of expenses for rewarding etc.

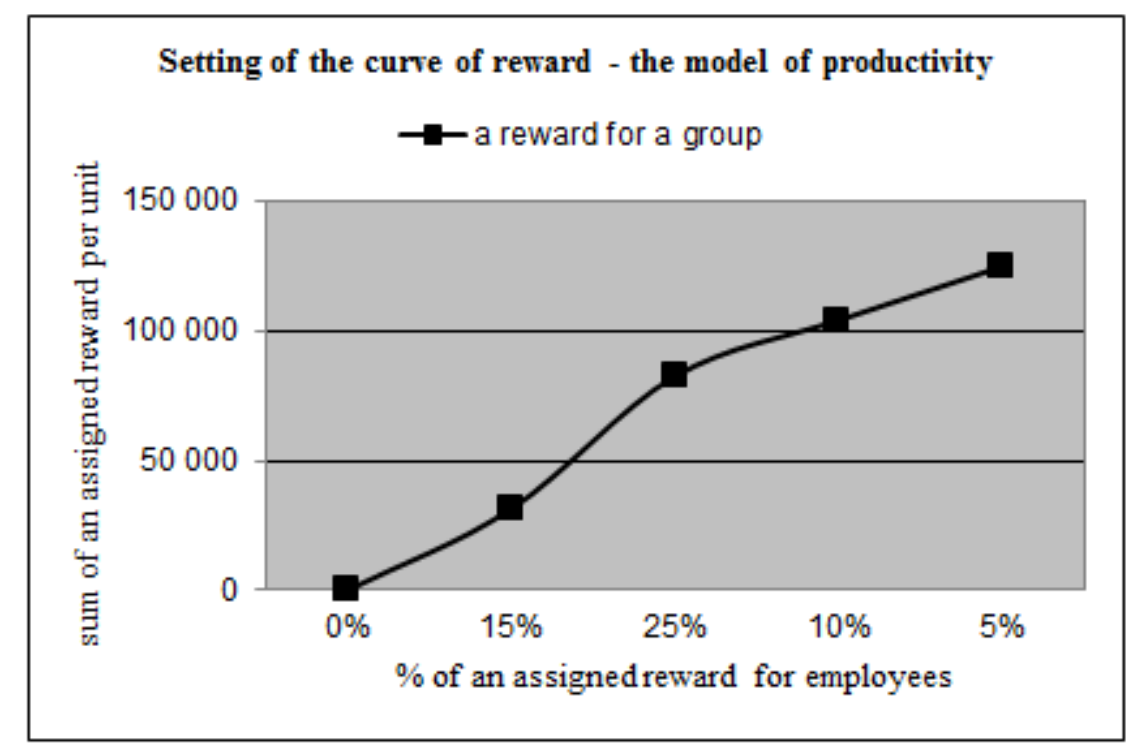

Grapf 1: Setting of the curve of reward - the model of productivity

Source: own work

It is also possible to use the model for making the measuring line of the rewarding, which is the most important phase during the application of a rewarding model. The measuring line is represented by a graph, which displays the sum of an assigned reward per unit. The unit is differentiated by the type of the model.

In a productivity model (see Grapf 1), the limit is used on the zero point and the limit of enhancement of productivity is increased by $10 \%$. One part from the profit is paid as a reward to the workers, who worked on the enhancement of productivity, and the second part is paid to a company. How big these parts are is up to the company. The model can be used also for this. When the limit of divding up the profit is (in 4 steps) determined, the profit is assigned to one point and the table of sums for individual points is calculated. This table is used by the model of productivity when there is some change. 


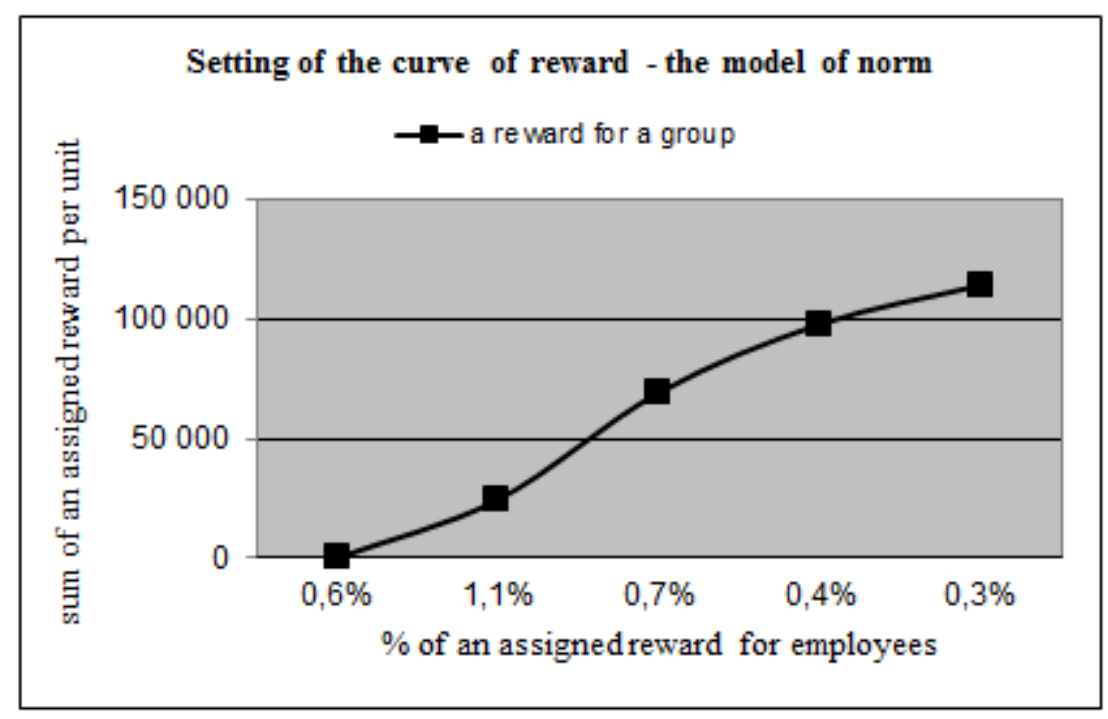

Grapf 2:The setting of a curve of rewarding (the model of norm)

Source: own work

The principle is similar for the model of norms (see Grapf 2). After a calculation of the transition point, the sum of the profit during a fulfillment of the norms by $110 \%$ is determined, and from this point on the procedure is analogical.

When there is an increase per unit, the graph will be re-drawn and there will also be a change of numbers in the income statement. This way, a manager can set the optimum curve of rewards as he wishes and observe the changes in the management of a company. The displaying of the model is completed by a graph following the development of the most important numbers in the income statement, such as sales, profits, expenses of salaries etc.

\section{Conclusion}

Rewarding of employees not only from manual professions is a complex problem. There is always a lot of different opinions on the correct rewarding. This model aims to help with the correct setting and offers the possibility to model the curve, watch the changes and help with decision making. The determination of zero point, the sum of the share of employees on the increased profit, and the reward for a change by zero point or percentage, will probably evoke heated debate in every company. This model does not intend to set a dogma or an absolute truth for all the companies. The aim is to simplify and display the changes in the expenses and revenues for each alternative.

One of the aims in this article, is to introduce the basic possibilities of rewarding employees of manual professions. The next goal is the description of function and the main idea of a prediction model and its partial goals, which are:

1. enable the selection of the correct rewarding system and recognize the necessary data (or resources) needed for its establishment.

2. help with the setting of the measuring line.

3. display the influence of results and expenses of the company during the establishment of given system and the selection of the measuring line. 
I have been developing this model so it can be usable, and user friendly for managers, for whom it is especially designed. That is why I have chosen MS Excel, as I assume the abilities and possibilities of MS Excel can be used by a greater number of users without any additional education or any other knowledge for its usage.

\section{Literatura}

[1] NOVÁK, J. Marketingový výzkum. 1. vyd. Praha: Grada, 2007, 285 s. ISBN: 80-7248111-1.

[2] AMSTRONG, M. Performance management. Key strategies and practical guidelines. London: Kogan Page Limited,2006. 216S. ISBN 0-7494-4537-8..

[3] ARMSTRONG M. Řizení lidských zdroji̊. Nejnovější trendy a postupy. 10.vyd. Praha: Grada Publishing, 2007. 789 s. ISBN 978-80-247-1407-3.

[4] BLÁHA, J., MATEICIUC, A., KAŇÁKOVÁ, Z. Personalistika pro malé a střední firmy. Brno: CP Books, 2005. 284 s. ISBN 80-251-0374-9.

[5] KOUBEK, J. Řízení pracovního výkonu. Praha: Management press, 2004. 209 s. ISBN 80-7261-116-X.

[6] SYNEK M. a kol.: Manažerská ekonomika. Praha 2006, Grada publishing. s.268. ISBN 80-247-0515-X.

[7] SIMANKOVA M.: Stimulační systémy zakázkových strojírenských společností (výsledky průzkumu), 2011. Dostupné online na http://stimulacni-systemy-zakazkovy.vyplnto.cz.

\section{JEL J33}

\section{Ing. Monika Šimánková}

Studentka doktorského studia

Fakulta podnikatelská

Vysoké učení technické v Brně

Kolejní 2906/4, 61200 Brno

sovikovam@email.cz 